\title{
Antibacterial and Anticancer Property of Bromelain: A Plant Protease Enzyme from Pineapples (Ananas comosus)
}

\author{
Jermen Mamo* and Fassil Assefa \\ Department of Microbial, Cellular and Molecular Biology, Addis Ababa University, Ethiopia
}

Submission: April 25, 2019; Published: June 06, 2019

*Corresponding author: Jermen Mamo, Department of Microbial, Cellular and Molecular Biology, College of Natural Science, Addis Ababa University, P.O.BOX 1176, Addis Ababa, Ethiopia

Abstract

Bromelain is an extract isolated from pineapple (Ananas comosus) mainly containing proteinase. It is a crude, aqueous extract from the stems and fruits of pineapples (Ananas comosus) derived from Bromeliaceae family. It has showed significant antibacterial activity against gram negative and gram positive bacteria such as Bacillus subtilis, Streptococcus pyogenes, Corynebacterium spp, Streptococcus sanguis (10556 ATCC), Enterococcus faecalis, Escherichia coli, Proteus spp and Pseudomonas aeruginosa. The anti- bacterial mechanism of bromelain is not well known but it may inhibit the growth of bacteria through hydrolysis of some peptide bonds present in the bacterial cell wall. Bromelain also showed significant anticancer activity against breast cancer cells, melanoma cells, human epidermoid carcinoma cells, malignant peritoneal mesothelioma cells and mammary carcinoma cells. The major anticancer mechanism of bromelain is by inhibiting cancer cell proliferation and inducing differentiation of leukemic cells.

Keywords: Bromelain; Anti-bacterial; Anti-cancer; Inhibitory effect; Carcinoma

Abbreviations: CPs: Cysteine Proteinases; TSS: Total Soluble Solids; NAC: N-Acetyl Cysteine

\section{Introduction}

Bromelain is an extract isolated from pineapple (Ananas comosus) mainly containing proteinase [1]. It is a crude, aqueous extract from the stems and fruits of pineapples (Ananas comosus) derived from Bromeliaceae family [2]. Pineapple is the common name of Ananas comosus (syn. A. sativus, Ananassa sativa, Bromelia ananas, B. comosa). It is the primary edible member of the family Bromeliaceae, grown in several tropical and subtropical countries comprising Indonesia, Philippines, Thailand, Malaysia, Kenya, India, and China [3].

Pineapple has been used as a medicinal plant in numerous instinctive cultures and these medicinal qualities of pineapple are attributed to bromelain. The chemical content of bromelain has been known since 1875 and is used as a phytomedical compound. The concentration of bromelain is high in pineapple stem, thus compelling its extraction, unlike the pineapple fruit which is normally used as food [4].

Bromelain is accumulated in various parts of the plant to different level and its properties vary based on its source [1]. Bromelain was primarily isolated from the stem and juice of the pineapple in the late 1800s [5]. Commonly bromelain is categorized as fruit bromelain and stem bromelain depending on its source, while all commercial bromelain is extracted from the stem [1]. Stem bromelain (EC 3. 4. 22. 32) is the major protease existing in extracts of the stem of pineapple whereas fruit bromelain (EC 3. 4. 22. 33) is the main enzyme existing in pineapple fruit juice [2]. Pineapple wastes such as core, peel, crown, and leaves can also contain bromalein in relatively smaller quantities as compared to those in the stem [6].

Bromelain contains a mixture of different proteases as well as phosphatase, glucosidases, peroxi- dases, cellulases and glycoprotein. Some other minor thiol endopeptidase, ananain, comosain, protease inhibitors and organically-bound calcium are also present in the pineapple bromelain [1,2]. It is deactivated at a temperature of $70^{\circ} \mathrm{C}$, which is lesser than papain [5].

It is made up of 212 amino acids and the molecular weight is $33 \mathrm{kDa}$. Bromelain is stable at $\mathrm{pH}$ value of $3.0-6.5$ and temperature range of 40 0C-65 0C with the optimum being 50 0C- 60 0C. Bromelain can be activated by calcium chloride, cysteine, bisulphate salt, $\mathrm{NaCN}, \mathrm{H}_{2} \mathrm{~S}, \mathrm{Na}_{2} \mathrm{~S}$ and benzoate. Though, bromelain is usually sufficiently active without adding any activators. Antitrypsin, estatin $\mathrm{A}$ and $\mathrm{B}$, iodoacetate, $\mathrm{Hg}^{++}, \mathrm{Ag}^{+}$ and $\mathrm{Cu}^{++}$are some of the compounds that inhibit bromelain [1]. 
Bromelain is a type of cysteine proteinases with similar amino acid sequences which is mainly used in the traditional medicine and industry. These enzymes show various proteolytic activities. Cysteine proteinases (EC 3.4.22, CPs), known as thiol proteinases, are extensively distributed among living organisms. Several cysteine proteinases (CPs) in plant cells are synthesized as precursors in the endoplasmic reticulum and then after subject to post-translational modifications to form the active mature proteinases [7]. They play a major role in different cellular and physiological functions. AcCP2, a cysteine proteinase from pineapple fruit (Ananas comosus L.) belonging to the C1A subfamily is a diversified proteinase in function, and its expression could cause the development of fruit in pineapple and resistance responses in transgenic Arabidopsis plants. Cysteine proteinases CPs in plants essentially play a part in vital cellular and physiological functions such as growth and seed germination, leaf and flower senescence, fruit ripening and resistance responses to biotic and abiotic stresses [7].

Bromelain is known for its clinical applications particularly in tumor growth modulation, blood coagulation, enhancement of antibiotic activity and anti-inflammatory properties. Bromelain has been used for meat tenderization, solubilization of cereal proteins, stabilization of beer, baking cookies, production of protein hydrolyzates, softening skins in leather and textiles [6].

\section{Types of cysteine protease derived from pine apples}

All the endopeptidases of the pineapple plant (Ananas comosus) have generally been referred to as 'the bromelains', and indeed, the name 'bromelain' was originally applied to any protease from any member of the family Bromeliaceae [8].

Bromelain is a crude aqueous extract rich in cysteine proteases obtained from stem and fruit of Bromeliaceae family, of which pineapple, a common name of Ananas comosus (syns. A. sativus, Ananassa sativa, Bromelia ananas, B. comosa), is the most known specie [9]. Cysteine protease of Ananas comosus have considerable commercial importance, due to their strong proteolytic activity against a broad range of protein substrates and because they are active over a broad range of $\mathrm{pH}$ and temperature [10]. The pineapple tissues contain at least four proteases with molar masses from 20 to $31 \mathrm{kDa}$ that belongs to papain superfamily: stem bromelain (EC 3.4.22.32), fruit bromelain (EC 3.4.22.33), ananain (EC 3.4.22.31) and comosain [9]. The major proteinase present in extracts of plant stem was stem bromelain, whilst fruit bromelain was the major proteinase in the fruit. Two additional cysteine proteinases were detected only in the stem: these were ananain and comosain [11].

Stem bromelain, is the major proteinase extracted from plant stem. It represents almost $90 \%$ of the proteolytically active material present in pineapple stem extract. Stem bromelain is a glycosylated, single-chain protein of $24.5 \mathrm{kDa}$, a pI value of 9.55, containing seven cysteines and therefore most probably three disulfide bonds. The secondary structure of stem bromelain is relatively unchanged between $\mathrm{pH}$ 7-10, although irreversibly lost above $\mathrm{pH}$ 10. The complete amino acid sequence of stem bromelain has been deduced and confirms it to be a member of the papain family (Table 1) [8].

Table 1: Characteristics of cysteine protease derived from Pineapples.

\begin{tabular}{|c|c|c|c|c|}
\hline Name (EC Number) & $\begin{array}{c}\text { Molecular Mass } \\
\text { (Dalton) }\end{array}$ & Isoelectric point & $\begin{array}{c}\text { Amino acid } \\
\text { sequence }\end{array}$ & Glycosylation \\
\hline $\begin{array}{c}\text { Stem bromelain } \\
\text { (3.4.22.32) }\end{array}$ & $23,800.00$ & $>10$ & 212 & glycosylated \\
\hline $\begin{array}{c}\text { Fruit } \\
\text { bromelain(3.4.22.33) }\end{array}$ & $23,000.00$ & 4.6 & 351 & $\begin{array}{c}\text { Amid et al. [2] Ali, et } \\
\text { al. [6], Omotoyinbo et } \\
\text { al. [20] }\end{array}$ \\
\hline Ananain(3.4.22.31) & $23,800.00$ & $>10$ & 216 & Notycosylated glycosylated \\
\hline Comosain & $24,400.00$ & $>10$ & 186 & Arshad et al. [17], \\
Amid et al. [2]
\end{tabular}

Fruit bromelain is the major bromelain extracted from plant fruit. Fruit bromelain constitutes $30-40 \%$ of the total fruit protein and represents almost $90 \%$ of the proteolytically active material of the pineapple fruit. Fruit bromelain has high proteolytic activity compared to stem bromelain, with broad $\mathrm{pH}$ optima for synthetic and protein substrates, although most assays are performed around neutral $\mathrm{pH}$. Fruit bromelain is a single-chain protein of approximately $25 \mathrm{kDa}$, with a pI of 4.6. It also contains seven cysteines like that of stem bromelain (Table 1) [8].

Ananain is the second most abundant endopeptidase of pineapple stem extract, comprising up to $5 \%$ of the total protein.
The pH optimum with both synthetic and protein substrates is close to neutral. Ananain has high proteolytic activity, and useful colorimetric substrates include azocasein, azocoll and hide powder azure; this high activity has prompted the development of ananain as a debriding agent for burn injuries. Ananain is a non-glycosylated, single-chain protein of $23.5 \mathrm{kDa}$ and pI.10. It contains seven cysteine residues and homology modeling indicates high structural similarity with caricain and papain (Table 1) [8].

Comosain is the least abundant endopeptidase of pineapple stem extract yet characterized, representing less than $1 \%$ of the total protein. Comosain is a single-chain glycoprotein of 24.5 
$\mathrm{kDa}$, pI 10, containing seven cysteines and therefore probably three disulfide bonds. It has a similar carbohydrate composition to stem bromelain, but a markedly different amino acid composition. N-terminal sequence data show that comosain is distinct from the other pineapple endopeptidases (Table 1) [8].

\section{Physical, Chemical and Biological properties of Bromelain}

The pineapple crown extract comprises $2.41 \%$ of pulp, a mean value of 1.6 total soluble solid, $0.83 \%$ of fructose, $0.51 \%$ of glucose and $0.30 \%$ of acid. This implies that the pineapple crown extract is acidic and had less sucrose content [7]. The optimum activity of fruit bromelain enzyme for azoalbumin is at a pH value of 7.5 and for azocasein is at 6.5 , at a temperature of $55{ }^{\circ} \mathrm{C}$. The fruit bromelain has optimum activity at a $\mathrm{pH}$ value of 7.7 for casein and at 6.5 for sodium caseinate at a temperature of $59{ }^{\circ} \mathrm{C}$. The optimum activity of crude fruit bromelain towards the hydrolysis of haemoglobin is recorded at a pH value of 2.9 and temperature of $37{ }^{\circ} \mathrm{C}$ (Table 2) [12].

Table 2: Physico-chemical and Biological properties of bromalein.

\begin{tabular}{|c|c|c|c|c|}
\hline $\begin{array}{l}\text { Physicochemical and } \\
\text { biological characteristics }\end{array}$ & $\begin{array}{c}\text { Stem } \\
\text { Bromelain }\end{array}$ & $\begin{array}{c}\text { Fruit } \\
\text { Bromelain }\end{array}$ & $\begin{array}{c}\text { From juice extract } \\
\text { (leaves, bark or stem) }\end{array}$ & References \\
\hline Molecular weight (KDa) & $\begin{array}{l}26-37 \\
24.54-24.47 \\
22.83 \\
\end{array}$ & $\begin{array}{l}\text { 24.5-32.5; } \\
\text { 39.05; }\end{array}$ & & $\begin{array}{l}\text { Bala et al. [16], Bhattacharria, [19]; Omotoyinboet al., } \\
\qquad[20]\end{array}$ \\
\hline$\%$ pulp & & 2.41 & & Nadzirah et al. [7] \\
\hline$\%$ TSS & & $14.2-20.5 ; 1.60$ & & Mitra et al, [18]; Nadzirah et al. [7], \\
\hline Protein $(\mathrm{mg} / \mathrm{mL})$ & & & 0.2 & Martins et al. [14] \\
\hline$\%$ carbohydrates & & 15-18, & & Mitra et al. [18] \\
\hline Amino-acid residue & $\begin{array}{l}\text { 212-219; } \\
196 ; 212 ;\end{array}$ & 315 & & $\begin{array}{l}\text { Bhattacharria, [19]; Arshad et al. [17], Omotoyinboet } \\
\text { al. [20], }\end{array}$ \\
\hline$\%$ acid & - & 0.3 & - & Nadzirah et al. [7]; \\
\hline Optimum pH & 4-9.8; 7-8; & $\begin{array}{l}2.9-9 ; 3.8-5 \\
3.94 ; 2.9-7.7\end{array}$ & $7-8 ; 5.5-8.0 ; 6-7$ & $\begin{array}{l}\text { Bala et al. [16], Martins et al. [14]; Mitra et al. [18]; } \\
\text { Nadzirah et al. [7]; Bhattacharria, [19]; Arshad et al. } \\
\text { [17], Corzo et al, [12]; Pavan et al. [4]; Silva et al. [32] }\end{array}$ \\
\hline Optimum Temp (0C) & $50-60 ; 40$ & $37-70 ; 37-59$ & $50-60,40-60$ & $\begin{array}{c}\text { Bala et al. [16], Martins et al. [14]; Silva et al. [32] } \\
\text { Arshad et al. [17] }\end{array}$ \\
\hline
\end{tabular}

The bromelain immobilized on calcium alginate beads showed best quality at $4 \%$ alginate solution. Bromelain (leaf, green fruit, and ripened fruit) activity has showed the maximum activity towards hemoglobin as compared with other substrates (Casein, Ovalbumin, Peptone and Gelatin). Free bromelain from leaf, green fruit and ripe fruit has optimum activity at $\mathrm{pH}$ value of 5.5, 7.5 and 6.5 respectively. Immobilized bromelain from green and ripe fruit have maximum activity at a $\mathrm{pH}$ value of 7.5 while leaf bromelain has maximum activity at a $\mathrm{pH}$ value of 6.5 . Free and immobilized bromelain have optimum activity at a temperature of $50{ }^{\circ} \mathrm{C}$. Both the free and immobilized bromelain have maximum activity up on a period of $15 \mathrm{~min}$ [13]. The maximum activity of simple extracted bromelain enzyme is at a $\mathrm{pH}$ value of 7 and $50{ }^{\circ} \mathrm{C}$ and the maximum proteolytic activity for ethanol extracted bromelain enzyme is at pH 8 at $60{ }^{\circ} \mathrm{C}$ by using azocasein as substrate (Table 2).

The temperature stability profiles as a function of different time intervals showed higher retention of enzyme activity at low temperature. Incubation at $40{ }^{\circ} \mathrm{C}$ showed no loss of fruit bromelain activity up to $60 \mathrm{~min}$, whereas at $50{ }^{\circ} \mathrm{C}$ almost $83 \%$ of activity remained. Incubation at $80{ }^{\circ} \mathrm{C}$ for $8 \mathrm{~min}$ caused almost the loss of complete activity (Table 2 ) $[14,15]$.
The stem bromalen have a molecular weight range (26-37 $\mathrm{kDa}$ ), $\mathrm{pH}$ optimum range (6-7) and optimum temperature range of $50-60{ }^{\circ} \mathrm{C}[16]$. On the other hand, the fruit bromelain had been shown to have molecular weight range (24.5-32.5), optimum $\mathrm{pH}$ range of (3-8) and optimum temperature range of 37-70 ${ }^{\circ} \mathrm{C}$. Generally the molecular weight, $\mathrm{pH}$ and temperature optima for bromelain can be ranged from 24.5-37 kDa, 3-9 and 37-70 ${ }^{\circ} \mathrm{C}$ respectively (Table 2) [16].

Similarly, the activity stem bromelain (having 196 amino acids residue) with varies proteins substrate were showed an optimum $\mathrm{pH}$ of 7-8 and optimum temperature of $40^{\circ} \mathrm{C}$. However, the activities of fruit bromelain using different type's protein substrates were showed an optimum pH between 2.9-7.7 and an optimum temperature between $37-59{ }^{\circ} \mathrm{C}$ [17]. In another study, Mitra and his colleagues reported that the total soluble solids (TSS), the sugar content and the optimum $\mathrm{pH}$ of the pineapple must range from 14.2 to $20.5 \%, 15$ to $18 \%$ (w/v) and 3.8 to 5 [18]. The stem bromelain were also showed a molecular weight of 24.4-24.47 KDa, 212-216 amino acid residue and an optimum pH range of 4-9.8 (Table 2) [19].

According to Omotoyinbo and his colleague's, the stem bromelain had revealed a molecular weight of $22.83 \mathrm{KDa}$ and 
212 amino acid residue of while the fruit bromelain had a molecular weight of 39.05 and 315 amino acid residue [20]. The enzymatic activities of bromelain comprise a wide spectrum with $\mathrm{pH}$ range of 5.5 to 8.0 [4]. The optimal $\mathrm{pH}$ and temperature for the bromelain extracted from leaves of Curaua were 6-7 and 50-600C respectively (Table 2) [21].

\section{Absorption and Bioavailability}

Bromelain is absorbed from the gastrointestinal tract in a functionally intact form. Approximately $40 \%$ of labeled bromelain is absorbed in high molecular form from intestine [4]. The concentration of bromelain was found highest in the blood after one hour of administration. The experimental study had been revealed that, the oral administration of 8.6 gm of bromelain/ day have a half-life 6-9 hrs and 2.5-4ng/ ml concentration in plasma [22]. In a recent study, $3.66 \mathrm{mg} / \mathrm{mL}$ of bromelain is stable in artificial stomach juice after $4 \mathrm{hrs}$ of reaction and $2.44 \mathrm{mg} / \mathrm{mL}$ of bromelain remained in artificial blood after 4 hrs of reaction [4].

In other study, orally administered serine and cysteine proteases of plant and animal origin also reach blood and lymph as intact, high molecular weight and physiologically active protein molecules. Their absorption may be supported by a selfenhanced para-cellular transport mechanism resulting in subnanomolar concentration of transiently free protease molecules or, in a complex with anti-proteases, at higher concentrations [23].

The oral application of proteases leads to increased proteolytic activity of serum and amplified the anti-protease concentration of plasma. Their biological activity is determined by their proteolytic activity as free proteases on soluble peptides/ proteins or cell surface receptors (e.g. protease activated receptors) and their activity in the complex formed with their specific and/or unspecific anti-proteases. Oral administration of enteric coated tablets containing proteolytic enzymes of plant and animal origin may be a safe method to stabilize, positively influence or enhance physiological and immunological processes during disease developments and in healthy consumers [23].

\section{Side effect and toxicity of bromelain}

The toxicity of bromelain with an LD50 (lethal doses) in mice, rats and rabbits is very low which is greater than 10 $\mathrm{g} / \mathrm{kg}$. The administrations of $750 \mathrm{mg} / \mathrm{kg}$ of bromelain per day have not showed any toxic effect on dogs after 6 months. Administration of $1500 \mathrm{mg} / \mathrm{kg}$ per day to rats showed no carcinogenic or teratogenic effects and did not provoke any alteration in food intake, histology of heart, growth, spleen, kidney, or hematological parameters. After giving bromelain (3000 FIP unit/day) to human over a period of ten days found no significant changes in blood coagulation parameters [4].

In human clinical tests, side effects are generally not observed; however, caution is advised if administering bromelain to individuals with hypertension, since one report indicated individuals with pre-existing hypertension might experience tachycardia following high doses of bromelain. The allergenic potential of proteolytic enzymes should not be underestimated. They can cause IgE-mediated respiratory allergies of both the immediate type and the late-phase of immediate type. Bromelain, due to its use as a meat tenderizer and to clarify beer, is considered a potential hidden dietary allergen [24].

\section{Extraction and Purification of Bromelain}

\section{Extraction}

Fresh pineapple stem parts are collected and washed with $0.1 \%$ hydrogen peroxide solutions, peeled off, cut into small pieces and weighed. In the presence of sodium acetate buffer $\mathrm{pH}$ : 7.0; Conc.: $100 \mathrm{mM}$ ), juice is extracted from the fresh pineapple stem part by homogenization and then exposed to filtration. Then after, five-hundred $\mathrm{ml}$ of filtrate is collected and preserved using benzoic acid/sodium benzoate at a concentration of 1 $\mathrm{gm} / \mathrm{kg}$ of stem. This filtrate is called crude extract, and used as source of stem bromelain [1].

Purely ripe pineapple fruits are taken, cleaned and cut into small slices. The weighed mass is collected into a beaker, extracted using a homogenizer and filtered. Sodium benzoate is added to the filtered mass as a preservative at a concentration of $0.2 \mathrm{~g}$ for each $100 \mathrm{ml}$ of filtrate to serve as a preservative. The filtrate is labeled as fruit crude extract, and used as source of fruit bromelain [1].

\section{Purification}

The crude lysates (SCL and FCL) are centrifuged for 10 minutes at 2,000 rpm, 10 minutes at 4,000 rpm and 15 minutes at 4,000 rpm consecutively. The supernatants collected from the centrifugation can be labelled as 'Stem Crude Extract' (SCE) and 'Fruit Crude Extract' (FCE) for stem and fruit, respectively.1

\section{Ammonium sulphate precipitation}

Ammonium sulphate precipitations are carried out on both enzymes' crude extract, by adding $13.2 \mathrm{~g}$ of ammonium sulphate salt, pinch by pinch, to $30 \mathrm{ml}$ Stem Crude Extract and Fruit Crude Extract with continuous stirring for 45 minutes each. The sample solutions are then incubated overnight at $4{ }^{\circ} \mathrm{C}$. After the incubation, the precipitated enzymes are centrifuged at 4,000 rpm for 30 minutes. The pellet of both extracts are collected and dissolved in $10 \mathrm{ml}$ of $10 \mathrm{mM}$ Tris $\mathrm{HCl}$ buffer (pH: 8.0) [1].

\section{Ion exchange chromatography}

A beds of $15 \mathrm{~cm}$ thickness made of diethylaminoethyl (DEAE) cellulose is prepared in a chromatography column and equilibrated with $0.5 \mathrm{M}$ sodium phosphate buffer solution ( $\mathrm{pH}$ : 8.0). Then it is eluted by buffer 1 ( $\mathrm{pH}$ : 8.1) which contains; 25 $\mathrm{mM}$ Tris $\mathrm{HCl}$ and $25 \mathrm{mM} \mathrm{NaCl}$. The enzyme extract is poured onto the column, from the sides, without disturbing the DEAE cellulose bed and allowed to settle. The sample is eluted using 
the first eluting buffer 1 (i.e. $25 \mathrm{mM}$ Tris $\mathrm{HCl}$ and $25 \mathrm{mM} \mathrm{NaCl}$ ), $\mathrm{pH}: 8.1$ ) at a flow rate of 6 drops per minutes and the eluate is collected in $5 \mathrm{ml}$ capacity plain container [1].

The same process of elution is carried out using solution buffer 2, 3, 4, 5 and 6 containing $50 \mathrm{mM}, 75 \mathrm{mM}, 100 \mathrm{mM}, 125$ $\mathrm{mM}$ and $150 \mathrm{mM} \mathrm{NaCl}$, respectively (pH: 8.1). The enzyme samples are poured onto the column again but with the enzyme being eluted using eluting buffer $2(10 \mathrm{ml}$ of $25 \mathrm{mM}$ Tris $\mathrm{HCl}$ and $50 \mathrm{mM} \mathrm{NaCl}$ ), pH: 8.1. The process of elution is continued using eluting buffers 3, 4, 5 and 6 containing $75 \mathrm{mM}, 100 \mathrm{mM}, 125$ $\mathrm{mM}$ and $150 \mathrm{mM}$ of $\mathrm{NaCl}$, respectively. Finally, all ion-exchange eluates $(5 \mathrm{ml}$ each) are assayed for enzyme activities and total protein concentrations determined by Bradford method [1].

\section{Antibacterial activity of bromelain}

The development of antibiotic-resistance in pathogenic microorganisms such as E.coli, Enterococci, Staphylococci, Salmonella, Campylobacter, fungi and Candida cause difficulty to treat various disease. This growing problem of microbial resistance to drugs has led to various actions for the development of new drugs, understanding the mechanism of resistance and controlled use of antibiotics [25].

The search for new sources of antibiotics is a global challenge concerning different research institutions and pharmaceutical companies due to the emergence of drug resistant in pathogens. Infectious diseases are one of the world's major burdens to human health and account for almost 50,000 deaths every day. The situation has been more complex with the quick development of multidrug resistant micro-organisms. Traditional medicine is the solitary accessible and affordable treatment available in developing countries. Medicinal plants with healing compounds have been in use as therapies for human diseases since early civilization. In recent time, the demand for the medicinal plants is growing in both developing and developed countries due to increasing recognition of natural products as being non-toxic, devoid of side effects, easily available and of affordable prices [26].

Bromelain is known for its clinical applications particularly modulation of tumour growth, blood coagulation, enhancement of antibiotic action and anti-inflammatory properties [6].

\section{Antibacterial activity of bromelain against gram positive bacteria}

The gram positive bacteria Bacillus subtilis and Streptococcus pyogenes are resistant to both crude bromelain extract $(1.8 \mathrm{mg} / \mathrm{ml})$ and standard bromelain $(2 \mathrm{mg} / \mathrm{ml})$ in neutral $\mathrm{pH}$ at an incubation temperature of $25{ }^{\circ} \mathrm{C}, 37{ }^{\circ} \mathrm{C}$ and $45{ }^{\circ} \mathrm{C}$. But the gram positive bacteria, Corynebacterium spp is inhibited by crude bromelain extract $(1.8 \mathrm{mg} / \mathrm{ml})$ in neutral $\mathrm{pH}$ by showing an inhibition zone of $8.33 \mathrm{~mm}, 8.33 \mathrm{~mm}$ and $9.33 \mathrm{~mm}$ at a temperature of $25{ }^{\circ} \mathrm{C}, 37{ }^{\circ} \mathrm{C}$ and $45{ }^{\circ} \mathrm{C}$ respectively. The crude bromelain extract $(1.8 \mathrm{mg} / \mathrm{ml})$ completely inhibited Bacillus subtilis and Streptococcus while failed to inhibit the growth of Corynebacterium spp at $\mathrm{pH}$ value of 10.00 and temperature of 37 ${ }^{\circ} \mathrm{C}$ (Table 3) [6].

In another study, the minimum inhibitory concentration (MIC) of vancomycin against Streptococcus sanguis (10556 ATCC) decreased from $1 \mu \mathrm{g} / \mathrm{ml}$ to $0.5 \mu \mathrm{g} / \mathrm{ml}$ when combined with pineapple extract at concentrations up to $32 \mu \mathrm{g} / \mathrm{ml}$ [27]. Bromelain has been also showed antibacterial activity against Streptococcus mutant with a minimum inhibitory concentration of $2 \mathrm{mg} / \mathrm{ml}$ [28]. But, the bromelain enzyme extracted from leaves and stem of pineapple did not show antagonistic effect against Enterococcus faecalis [29]. A bromelain at concentration of $1 \mathrm{mg} / \mathrm{ml}$ tested against $L$. monocytogenes at $25{ }^{\circ} \mathrm{C}$ reduced 5.7 $\log \mathrm{CFU} / \mathrm{ml}$ populations after $48 \mathrm{~h}$ of incubation (Table 3) [30].

Table 3: Antibacterial activity of Bromelain against gram positive and gram negative Bacteria.

\begin{tabular}{|c|c|c|c|}
\hline Compound & \multicolumn{2}{|r|}{ Type of inhibited Microorganisms } & References \\
\hline Bromelain & Gram negative & $\begin{array}{l}\text { E. coli; Proteus Spps; Porphyromonas gingivalis; } \\
\text { Aggregatibacter actinomycetemcomitanst; Acinetobacter } \\
\text { spp; Pectobacterium carotovorum ssp Carotovorum; } \\
\text { Streptobacillus sp.; Pseudomonas aeruginosa }\end{array}$ & $\begin{array}{l}\text { Ali et al. [6], Praveen et al. [29], Krishnan, et al. } \\
\text { [30], Shweta Alai, [33] Basavegowda et al. [35], } \\
\text { Ajibade et al. [27], 2015, Eshamah et al. [31] }\end{array}$ \\
\hline & Gram positive & $\begin{array}{l}\text { Corynebacterium spp; Bacillus subtilis; Streptococcus } \\
\text { pyogenes; Streptococcus sanguis; Streptococcus mutant; } \\
\text { Enterococcus faecalis; L. monocytogenes; Streptococcus } \\
\text { pneumonia; Staphylococcus aureus }\end{array}$ & $\begin{array}{l}\text { Ali et al. [6], Khosropanah et al. [28], Praveen et } \\
\text { al. [29], Krishnan, et al. [30], Eshamah et al. [31], } \\
\text { Maria dos Anjos, et al., [32], Ajibade et al. [27], }\end{array}$ \\
\hline
\end{tabular}

The bromelain also showed antagonistic effects against Alicyclobacillus acidoterrestris strain, with the MIC of 62.5 $\mu \mathrm{g} / \mathrm{mL}$ and MBC of $250 \mu \mathrm{g} / \mathrm{mL}$. The concentration of $4 \times$ MIC for bromelain enzymes is sufficient to eliminate 4 logs of the microorganism after $24 \mathrm{~h}$ of incubation (Table 3) [31].

According to [26], the antimicrobial effect of crude extract of oven dried pine apple against Streptococcus pneumoniae and Staphylococcus aureus with a concentration of $0.2-1.0 \mathrm{gm} / \mathrm{ml}$ were showed an inhibition zone that ranges from 5-13 $\mathrm{mm}$ and $6-12 \mathrm{~mm}$ respectively. This result indicates that, the pineapple extract are effective on the test bacteria due to the exhibition of wide zones of inhibition (Table 3).

\section{Antibacterial activity of bromelain against gram negative bacteria}

The crude bromelain extract $(1.8 \mathrm{mg} / \mathrm{ml})$ inhibited the gram negative bacteria, sucrose positive Escherichia coli and Proteus 
spp with various diameter of inhibition zone at neutral $\mathrm{pH}$ and temperature of $25{ }^{\circ} \mathrm{C}, 37{ }^{\circ} \mathrm{C}$ and $45{ }^{\circ} \mathrm{C}$. The maximum inhibitory activity of crude bromelain extract $(1.8 \mathrm{mg} / \mathrm{ml})$ is noticed against Proteus spp in comparison to sucrose positive Escherichia coli at a temperature of $37{ }^{\circ} \mathrm{C}$ and $\mathrm{pH}$ of 10.00.6 Bromelain also showed antimicrobial activity against Porphyromonas gingivalis, Aggregatibacter actinomycetemcomitanst and Escherchia coli at a minimum inhibitory concentration of $4.15 \mathrm{mg} / \mathrm{ml}, 16.6 \mathrm{mg} /$ $\mathrm{ml}$ and $31.25 \mathrm{mg} / \mathrm{ml}$ respectively[28]. Similarly, the bromelain enzyme extracted from leaves $(0.024 \mathrm{mg} / \mathrm{ml})$ and stem $(0.048$ $\mathrm{mg} / \mathrm{ml}$ ) of pineapple has been showed antagonistic effect against pathogens of periodontitis such as Aggregatibacter actinomycetemcomitans and Porphyromonas gingivalis (Table 3) [29].

In other study, bromelain inhibited colonies of Acinetobacter spp on media plates by forming $24 \mathrm{~mm}$ diameter of inhibition zone 32]. A bromelain concentration of $4 \mathrm{mg} / \mathrm{ml}$ reduced 3.37 $\mathrm{CFU} / \mathrm{ml}$ of $E$. coli population at a temperature of $25{ }^{\circ} \mathrm{C}$ within 48 h of incubation (Table 3) [30].

The overexpression of BAA1gene (the gene encoding fruit bromelain) in transgenic Chinese cabbage (Brassica rapa) improve resistance to the soft rot pathogen Pectobacterium carotovorum ssp. Carotovorum [33]. The synthesized gold nanoparticles fruit extracts of Ananas comosus have antimicrobial activity against E.coli and Streptobacillus sp. (Table 3) [34].

The antimicrobial effect of crude extract of oven dried pine apple against Pseudomonas aeruginosa with a concentration of 0.2-1.0 gm/ $\mathrm{ml}$ were showed an inhibition zone that ranges from $7.5-13 \mathrm{~mm}$. This result indicates that, the pineapple extract are effective on the Pseudomonas aeruginosa due to the exhibition of wide zones of inhibition (Table 3) [26].

\section{Antibacterial mechanism of bromelain}

The mechanism by which bromelain hinders the growth of bacteria is not well known. But bromelain may inhibit the growth of bacteria through hydrolysis of some peptide bonds present in the bacterial cell wall. 6 When bromelain digested the surface proteins, the cell wall damaged and allows leakage, swelling of the cell and finally cell breakage [30].

The effect bromelain against Vibrio cholera and Escherchia coli that whose enterotoxin cause diarrhea in animals may also be due to its interaction with intestinal secretory signaling pathways, which comprises the adenosine $3^{\prime}: 5^{\prime}$-cyclic monophosphatase, guanosine $3^{\prime}: 5^{\prime}$-cyclic monophosphatase and calcium-dependent signaling cascades. Bromelain also inhibit the growth of $E$. coli by preventing the adhesion of the bacteria to specific glycoprotein receptors located on the intestinal mucosa [28].

The fruit bromelain inhibit the growth Acinetobacter spp by decreasing lectin excretion which supports the bacteria in colonization of respiratory tract of humans [32]. The antibacterial mechanism of bromelain against Alicyclobacillus acidoterrestris is not related to its proteolytic activity, but may be linked to amidse and esterase [31].

The prescription of bromelain in blend with antibiotics raises the antibacterial effects of the drug against streptococcus and thus reduces the minimum inhibitory concentration of the antibiotic. Hence, lower doses of the antibiotic would be needed to treat the streptococcal infection when antibiotics are used along with bromelain. This might be due to the activity of bromelain increasing the absorption of antibiotics which leads to better distribution of the drug in the tissues of the microbes [27].

In other study, the oral administration of bromelain has been effectively reduced the incidence of K88+ enterotoxigenic Escherichia coli diarrhoea in piglets and protected piglets from life threatening disease. The establishment of diarrhoal disease depends on the attachment of K88+ enterotoxigenic Escherichia coli to glycoprotein receptors on the mucosa of small intestinal. The possible way by which bromelain preventing ETEC diarrhoea is through preventing the attachment of bacteria by modifying receptor attachment sites proteolytically, as ETEC receptors are highly sensitive to protease activity. Therefore, the oral administration of bromelain, a proteolytic extract from pineapple stems, may possibly inhibit ETEC receptor activity and K88+ ETEC attachment to porcine small intestine [35].

\section{Anticancer activity of Bromelain}

Bromelain showed significant inhibitory effect against melanoma cells. Application of bromelain $(60 \mathrm{mg} / \mathrm{ml})$ as a treatment in to $\mathrm{C} 57 \mathrm{Bl} / 6$ mice injected with B16F10-Nex2 melanoma cells intravenously (that cause significant lung colonization after 21 days) on the same day of intravenous, greatly reduced the number of lung metastatic nodules and finally resulted to the absence of metastatic tumor nodules in the myocardium, brain, kidney, liver, and spleen (Table 4) [36].

Bromelain also showed anti-tumour property against malignant peritoneal mesothelioma cells. Bromelain as a single agent has a dramatic effect on cell viability of both YOU and PET cells (Malignant Peritoneal Mesothelioma Cells). There is a linear relationship between bromelain concentration and cell death in both the cell lines, with an IC50 value of $54 \mathrm{ug} / \mathrm{ml}$ bromelain (Table 4) [37].

Combination of N-Acetyl Cysteine (NAC) (10 mM) with bromelain $(75 \mathrm{ug} / \mathrm{ml}$ ) showed $97 \%$ and $88 \%$ cell proliferation inhibition in YOU and PET cells (Malignant Peritoneal Mesothelioma), respectively. In triple combination, the addition of cisplatin to only $5.0 \mathrm{mM} \mathrm{NAC}$ and bromelain increased cytotoxicity in YOU cells but absent at 10.0 mM NAC concentration. However, in PET cells, triple combinations with cisplatin had no effect [20]. But, the cytotoxicity seems to be enhanced by the addition of N-Acetyl Cysteine (NAC) to bromelain, as shown by 
decreasing values in IC 50 (50\% inhibition of cell viability) with additions of various quantities of NAC. Further, the maximum inhibition of cell viability (I max) took place at the higher end of bromelain and NAC concentrations $(25 \mathrm{mM} \mathrm{NAC}+75 \mathrm{ug} / \mathrm{ml}$ bromelain; $50 \mathrm{mM} \mathrm{NAC}+75 \mathrm{ug} / \mathrm{ml}$ bromelain) for YOU cells (Table 4) [37].

Table 4: Anti- cancer activity of bromelain against various cancerous cells.

\begin{tabular}{|c|c|c|}
\hline Compound & Cancerous cells inhibited by the activity of bromelain & References \\
\hline \multirow{4}{*}{ Bromelain } & B16F10-Nex2 and A375 Melanoma cells & Guimarães-Ferreira et al. [36], Bhui et al. [40], Grabowska et al. [43] \\
\cline { 2 - 3 } & Malignant peritoneal mesothelioma cells & Pillai et al. [38] \\
\cline { 2 - 3 } & MCF-7 breast cancer cells & Fouz et al. [39], Bhui et al. [41] \\
\cline { 2 - 3 } & Human epidermoid carcinoma-A431 & Bhui et al. [40] \\
\cline { 2 - 3 } & p-388 leukemia cells & Baez, et al. [42] \\
\hline
\end{tabular}

The cytotoxic effect of commercial and recombinantbromelain on MCF-7 breast cancer cells is very strong. The commercial and recombinant bromelain have showed an inhibitory effect against proliferation of MCF-7 breast cancer cells at IC50 values of $5.13 \mu \mathrm{g} / \mathrm{mL}$ and $6.25 \mu \mathrm{g} / \mathrm{mL}$, respectively. This indicates that commercial and recombinant bromelain have anti-proliferative activity and reduced the number of cell generations from 3.92 to 2.81 for commercial bromelain and to 2.86 for recombinant bromelain. Microscopic observation of bromelain-treated MCF-7 breast cancer cells demonstrated detachment. Inhibition activity is verified with growth rates decreased dynamically from 0.009 h-1 to $0.0059 \mathrm{~h}-1$ for commercial bromelain and to $0.0063 \mathrm{~h}-1$ for recombinant bromelain (Table 4) [38].

Bromelain have been also showed inhibitory effect against the growth and proliferation of human epidermoid carcinoma cells. Bromelain with a concentration of $(50-900 \mathrm{mg} / \mathrm{mL})$ inhibited cell growth and proliferation of human epidermoid carcinoma-A431 and melanoma-A375 cells within 6 to $48 \mathrm{hrs}$. The IC50 of bromelain is $200 \mathrm{mg} / \mathrm{mL}$ for A431 cells and 400 $\mathrm{mg} / \mathrm{mL}$ for A375 cells, on $48 \mathrm{~h}$ exposure time. The response to bromelain followed similar pattern in both cell types; A431 cells being more sensitive than A375 cells. Bromelain also down regulated the expression of anti-apoptotic gene Bcl-2 and up regulated expression of apoptotic genes Bax (Ratio of Bax to Bcl2 increased), Apaf- 1 , caspases- 9 , and -3 of A431 cells within 48 $\mathrm{h}$, and this is supporting evidence of apoptotic cell death (Table 4) [39].

Bromelain from pineapple also possesses potent anticancer effects against mammary carcinoma cells through facilitating apoptotic response. Bromelain have been showed inhibitory effects on human breast cancer MCF-7 cell growth with an IC50 value at $60 \mu \mathrm{g} / \mathrm{mL}$ within $96 \mathrm{~h}$. However, in human breast cancer MDA-MB-231 cells, the IC50 value of bromelain achieved at 50 $\mu \mathrm{g} / \mathrm{mL}$ within $72 \mathrm{~h}$ (Table 4) [40].

The treatment of transplanted animals (mice injected with p-388 leukemia cells and developed ascites in the peritoneal cavity) with bromelain at concentration of $1 \mathrm{mg} / \mathrm{kg}, 5 \mathrm{mg} / \mathrm{kg}$, $12.5 \mathrm{mg} / \mathrm{kg}$ and $25 \mathrm{mg} / \mathrm{kg}$ had increased the survival percentage of the animal $16 \pm 3$ days (141\%), 19 \pm 2 (169\%), 18 \pm 1 (157\%) and $18 \pm 2$ (160) respectively as compared to transplanted animals without treatment that showed a survival percentage of $11 \pm 2$ (100\%). The treatment of transplanted animal with bromelain also reduced the size of spleen from $1190.75 \mathrm{~g}$ to 564.57 (Table 4) [41].

The application of bromelain F9 in to melanoma cells in vitro as a treatment before intravenous injection into mice prevents lung colonization. The lung weight at day 20 was significantly reduced from 5.1\% (untreated cells) to $1.6 \%$ (bromelain F9 treated cells). However, there was no difference in the lung weight between bromelain F9 treated and the untreated group at day 27. The removal of protease and further incubation of the B16F10 cells retained their capacity to prompt lung tumor metastases (Table 4) [42].

Bromelain was also found to be most active in reducing the density of $\mathrm{CD} 44$ receptor molecules present on human leukemia Molt 4/8 cell which is involved in leukocyte binding to endothelium and metastatic spread of tumor cells. On Molt $4 / 8$ cells, crude bromelain and F9, with the highest proteolytical activity, were found to be most active in reducing CD44 receptor density. On human SK-Mel 28 melanoma cells especially F9 showed a strong effect. This implies the antimetastatic activity of orally administrated bromelain with respect to CD44 is very high (Table 4) [43].

\section{Anticancer Mechanism of Bromelain}

The therapy used to treat cancer can reduce cancereous cells by several mechanisms such as inhibiting cancer cell proliferation directly by stimulating macrophage phagocytosis, by enhancing natural killer cell activity, inducing apoptosis of cancer cells through maximizing the production of interferon, interleukin-2 immunoglobulin and complement in blood serum, enforcing the necrosis of tumor and inhibiting its translocation and spread by blocking the blood source of tumor tissue, enhancing the number of leukocytes and platelets by stimulating the hemopoietic function, promoting the reverse transformation from tumor cells into normal cells, promoting metabolism and preventing carcinogenesis of normal cells, stimulating appetite, improving quality of sleep, relieving pain, thus benefiting patient's health [44]. One of the anti-tumor mechanisms of bromelain may be by inducing differentiation of leukemic cells. This induction of cell 
differentiation result in apoptosis of tumor cells, a process by which many cytostatic drugs may eliminate tumor cells [45].

Bromelain inhibit the growth of cancer cells by increasing the expression of p53 and Bax activators genes of apoptosis in mouse skin. It also declines the activity of cell survival regulators such as Akt and Erk, as a result promoting apoptotic cell death in tumours. Bromelain down regulate NF- $\mathrm{kB}$ and Cox- 2 (promoters of cancer progression) expression in mouse papillomas and in models of skin tumourigenesis as a mechanism for treatment of cancer cells [4]. Evidence shows that the signaling and over expression of NF- $\kappa B$ plays an important part in many types of cancers. Cox-2, a multiple target gene of NF- $\kappa \mathrm{B}$, facilitates the conversion of arachidonic acid into PGE2 and thus stimulates tumour angiogenesis. Therefore, inhibiting NF- $\mathrm{B}$, Cox-2, and PGE2 activity has potential as a treatment of cancer [3]. It also shows to inhibit bacterial endotoxin (LPS)-induced NF- $\mathrm{BB}$ activity as well as the expression of PGE2 and Cox-2 in human monocytic leukemia and murine microglial cell lines [4].

Bromelain significantly inhibit the expression of cyclooxygenase-2 (Cox-2) and inactivation of nuclear factorkappa B (NF-jB) by blocking phosphorylation and consequent degradation of IK $\mathrm{B} \alpha$. Also, bromelain treatment reduced extracellular signal regulated by protein kinase (ERK1/2), p38 mitogen-activated protein kinase (MAPK) and Akt activity. The basis of anti-tumor-initiating activity of bromelain was revealed by its time dependent reduction in DNA nick formation and increase in percentage prevention. Thus, modulation of inappropriate cell signaling cascades driven by bromelain is a major approach in achieving chemoprevention [46] The lung metastasis induced by LLC (Lewis lung carcinoma) transplantation is significantly reduced by bromelain. The antitumoral activity of bromelain against S-37 and EAT (Ehrlich ascitic tumor) and the unchanged tumor progression in the metastatic model suggests that the anti-metastatic action results from a mechanism independent of the primary anti-tumoral effect [44].

\section{Conclusion}

Bromelain is a plant cysteine protease enzyme extracted from the stem and leaf of pine apple (Ananas comosus). It has been showed efficient antibacterial effect in hindering the growth of both gram negative and gram positive bacteria such as Streptococcus mutant, L. monocytogenes, Alicyclobacillus acidoterrestris, sucrose positive Escherichia coli, Proteus spp, Porphyromonas gingivalis, Aggregatibacter actinomycetemcomitanst, and Porphyromonas gingivalis. It also showed anticancer activity against melanoma cells, malignant peritoneal mesothelioma cells, breast cancer cells, human epidermoid carcinoma cells and mammary carcinoma cells.

\section{References}

1. Gautam SS, Mishra SK, Dash V, Goyal AK, Rath G (2010) Comparative study of extraction, purification and estimation of bromelain from stem and fruit of pineapple plant. TJPS 34: 67-76.
2. Bala M, Mel M, Jami MS, Amid A, Salleh HM (2013) Kinetic studies on recombinant stem bromelain. Adv in Enzyme Res 1(3): 52-60.

3. Chakraborty DS (2015) Anti-metastatic mechanism and efficacy of bromelain. Int J Ayur Pharm Res 3(1): 10-13.

4. Pavan R, Shraddha SJ, Kumar A (2012) Properties and therapeutic application of bromelain: A review. Biotechnol Res Int doi:10.1155/2012/976203.

5. Rao MB, Tanksale AM, Ghatge MS, Deshpande VV (1998) Molecular and biotechnological aspects of microbial proteases. Microbiol Mol Biol 62(3): 597-635.

6. Ali AA, Milala MA, Gulani IA (2015) Antimicrobial effects of crude bromelain extracted from pineapple fruit (Ananas comosus (Linn.) Merr.) Adv in Biochem 3(1): 1-4.

7. Nadzirah KZ, Zainal S, Noriham A, Normah I, Siti Roha AM (2012) Physico-Chemical properties of pineapple crown extract variety N36 and bromelain activity in different forms. APCBEE Procedia, 4: 130134.

8. Rowan AD (2013) Hand Book of Proteolytic Enzymes: Stem Bromelain. ( $3^{\text {rd }}$ edn). Elsevier Ltd. Pp 1871-1877.

9. Elisa R (2017) Debridement Applications of Bromelain: A Complex of Cysteine Proteases from Pineapple 3(4): 555624.

10. Feijoo-siota L, Villa TG (2010) Native and Biotechnologically Engineered Plant Proteases with Industrial Applications.

11. Rowan AD, Buttlet DJ, Barrett AJ (1990) The cysteine proteinases of the pineapple plant 266: 869-875.

12. Corzo CA, Waliszewski KN, Welti-Chanes J (2012) Pineapple fruit bromelain affinity to different protein substrates. Food Chemistry 133: 631-635.

13. Sree Padma Priya SP, Jayakumar K, Mathai V, Chintu S, Sarath Babu K (2012) Immobilization and kinetic studies of bromelain: A Plant cysteine protease from pineapple (Ananas comosus) plant parts. Int J Med Health Sci 1: 10-16.

14. Martins BC, Rescolino R, Coelho DF, Zanchetta B, Tambourgi EB, et al. (2014) Characterization of Bromelain from Ananas Comosus Agroindustrial Residues Purified by Ethanol Factional Precipitation 37: 781-786.

15. Jutamongkon R, Charoenrein S (2010) Effect of temperature on the stability of fruit bromelain from smooth cayenne pineapple. Kasetsart J (Nat Sci) 44: 943-948.

16. Bala M, Ismail NA, Mel M, Jami MS, Jami MS, et al. (2012) Bromelain Production: Current Trends and Perspective 65(11): 369-399.

17. Arshad ZI, Amid A, Yusof F, Jaswir I, Ahmad K, et al. (2014) Bromelain: An overview of industrial application and purification strategies Bromelain: an overview of industrial application and purification strategies. Appl Microbiol Biotechnol 98(17): 7283-7297.

18. Mitra B, Garg KV (2013) Deactivation of Bromelain in Pineapple Juice and analysing its Physico-Chemical and Organoleptic properties for successful commercialization via FMCG Industries in Indian Subcontinent. Int J Drug Dev \& Res 5(3): 138-145.

19. Bhattachariyya BK (2008) Bromelain: An overview. Natural Product Radiance 7(4): 359-363.

20. Omotoyinbo OV, Ekpenyong IE, Hezekiah T, Sanni MD (2018) In Silico evaluation of bromelain from stem and fruit of pineapple (Ananas comosus). Journal of Agricultural Science and Food Technology 4(2): $32-40$.

21. Alves T, Lima D, Rocha I, Pereira A, Maria G, et al. (2014) Extraction and Preliminary Characterization of Bromelain from Curaua (Ananas erectifolius L). Purple and White 37: 769-774. 
22. Dighe NS, Pattan SR, Merekar AN, Laware RB, Bhawar SB, et al. (2010) Bromelain A Wonder Supplement: A Review. Pharmacologyonline 1 11-18.

23. Lorkowski G (2012) Gastrointestinal absorption and biological activities of serine and cysteine proteases of animal and plant origin review on absorption of serine and cysteine proteases. Int J Physiol Pathophysiol Pharmacol 4(1): 10-27.

24. Thorne Research (2002) Bromelain. Alternative Medicine Review Monograph.

25. Wang W, Zhang L, Guo N, Zhang X, Zhang C, et al. (2014) Functional properties of a cysteine proteinase from pineapple fruit with improved resistance to fungal pathogens in Arabidopsis thaliana. Molecules 19(2): 2374-2389.

26. Sirohi P, Ranghar S, Khandelwal A, Poonia A, Sirohi A, et al. (2013) Herbal product based remedies against microbial infections and resistance. Weekly Sci Res J 1(8): 1-20.

27. Ajibade VA, Akinruli FT, Ilesanmi TM (2015) Antibacterial Screening of Crude Extract of Oven-Dried Pawpaw and Pineapple. Int J Sc Res Pub 5(11): 408-411.

28. Khosropanah H, Bazargani A, Ebrahimi H, Eftekhar K, Emami Z, et al. (2012) Assessing the effect of pineapple extract alone and in combination with vancomycin on Streptococcus sanguis. Jundishapur J Nat Pharm Prod 7(4): 140-143.

29. Praveen NC, Rajesh A, Madan M, Chaurasia VR, Hiremath NV, et al. (2014) In vitro evaluation of antibacterial efficacy of pineapple extract (bromelain) on periodontal pathogens. J Int Oral Health 6(5): 96-98.

30. Krishnan AV, Gokulakrishnan M (2015) Extraction, purification of bromelain from pineapple and determination of its effect on bacteria causing periodontitis. IJPSR 6(12): 5284-5294.

31. Eshamah H, Han I, Naas H, Rieck J, Dawson P (2013) Bactericidal effects of natural tenderizing enzymes on Escherichia Coli and Listeria monocytogenes. JFR 2(1): 8-18.

32. Maria dos Anjos M, Aparecida da Silva A, Carolini de Pascoli J, Mikcha JG, Machinski M, et al. (2016) Antibacterial activity of papain and bromelain on Alicyclobacillus spp. Int J Food Microbiol 216: 121-126.

33. Shweta Alai P (2014) Bromelain a cysteine protease: helps to reduce infection caused by Acinetobacter spp., a nosocomial pathogen. IJBR 15: 415-422.

34. Jung Y, Choi C, Park J, Kang H, Choi J, et al. (2008) Overexpression of the pineapple fruit bromelain gene (BAA) in transgenic Chinese cabbage (Brassica rapa) results in enhanced resistance to bacterial soft rot. Electron J Biotechnol 11(1): 1-8.
35. Basavegowda N, Sobczak-Kupiec A, Malina D, Yathirajan HS, Keerth VR, et al. (2013) Plant mediated synthesis of gold nanoparticles using fruit extracts of Ananas comosus (L.) (Pineapple) and evaluation of biological activities. Adv Mat Lett 4(5): 332-337.

36. Chandler DS, Mynott TL (1998) Bromelain protects piglets from diarrhoea caused by oral challenge with K88 positive enterotoxigenic Escherichia coli. Gut 43:196-202.

37. Guimarães-Ferreira CA, Rodrigues EG, Mortara RA, Cabral H, Serrano FA, et al. (2007) Antitumor effects in vitro and in vivo and mechanisms of protection against melanoma B16F10-Nex2 cells by fastuosain, a cysteine proteinase from bromelia fastuosa. Neoplasia 9(9): 723-733.

38. Pillai K, Akhter J, Ehteda A, Badar S, Chua TC (2013) Anti-Tumour and chemosensitising effect of a combination of bromelain $+\mathrm{N}$-Acetyl Cysteine with Cisplatin or 5-Fu on Malignant Peritoneal Mesothelioma Cells. J Glycobiol S1: 005.

39. Fouz N, Amid A, Has-Yun Hashim YZ (2014) Cytokinetic Study of MCF-7 Cells Treated with Commercial and Recombinant Bromelain. Asian Pac J Cancer Prev 14: 6709-6714.

40. Bhui K, Tyagi S, Srivastava AK, Singh M, Roy P, et al. (2012) Bromelain inhibits nuclear factor Kappa-B translocation, driving human epidermoid carcinoma A431 and melanoma A375 cells through G2/M arrest to apoptosis. Mol Carcinog 51(3): 231-243.

41. Bhui K, Tyagi S, Prakash B, Shukla Y (2010) Pineapple bromelain induces autophagy, facilitating apoptotic response in mammary carcinoma cells. Bio Factors 36(6): 474-482.

42. Baez R, Lopes MTP, Salas CE, Hernandez M (2007) In Vivo antitumoral activity of stem pineapple (Ananas comosus) bromelain. Planta med 73(13): 1377-1383.

43. Grabowska E, Eckert K, Fichtner I, Schulzeforster K, Maurer H (1997) Bromelain proteases suppress growth, invasion and lung metastasis of B16F10 mouse melanoma cells. Int J Oncol 11(2): 243-248.

44. Harrach T, Gebauer F, Eckert K, Kunze R, Maurer H (1994) Bromelain proteinases modulate the cd44 expression on human molt-4/8 leukemia and sk-mel-28 melanoma-cells in-vitro. Int J Oncol 5(2): 197 203.

45. Nataru S, Pulicherla Y, Gaddala B (2014) A review on medicinal plants as a potential source for cancer. Int J Pharm Sci Rev Res 26(1): 235-248.

46. Sharma A, Bist R, Poonam (2013) A natural way to cancer prevention and therapy. IJABPT 3: 9-22.

\section{Your next submission with Juniper Publishers} will reach you the below assets

- Quality Editorial service

- Swift Peer Review

- Reprints availability

- E-prints Service

- Manuscript Podcast for convenient understanding

- Global attainment for your research

- Manuscript accessibility in different formats

(Pdf, E-pub, Full Text, Audio)

- Unceasing customer service

Track the below URL for one-step submission https://juniperpublishers.com/online-submission.php 